\title{
Epicardial adipose tissue and severe Coronavirus Disease 19
}

\author{
Hélène Bihan ${ }^{1 *} \mathbb{D}$, Richard Heidar ${ }^{2}$, Aude Beloeuvre ${ }^{3}$, Lucie Allard ${ }^{1}$, Elise Ouedraogo ${ }^{4}$, Sopio Tatulashvili ${ }^{1}$, \\ Yacine Tandjaoui ${ }^{3}$, Stephane Gaudry ${ }^{3}$, Pierre-Yves Brillet ${ }^{2}$ and Emmanuel Cosson ${ }^{1,5}$
}

\begin{abstract}
Background: Both visceral adipose tissue and epicardial adipose tissue (EAT) have pro-inflammatory properties. The former is associated with Coronavirus Disease 19 (COVID-19) severity. We aimed to investigate whether an association also exists for EAT.
\end{abstract}

Material and methods: We retrospectively measured EAT volume using computed tomography (CT) scans (semiautomatic software) of inpatients with COVID-19 and analyzed the correlation between EAT volume and anthropometric characteristics and comorbidities. We then analyzed the clinicobiological and radiological parameters associated with severe COVID-19 (O2 $\geq 6 \mathrm{l} / \mathrm{min})$, intensive care unit (ICU) admission or death, and 25\% or more CT lung involvement, which are three key indicators of COVID-19 severity.

Results: We included 100 consecutive patients; $63 \%$ were men, mean age was $61.8 \pm 16.2$ years, $47 \%$ were obese, $54 \%$ had hypertension, $42 \%$ diabetes, and $17.2 \%$ a cardiovascular event history. Severe COVID-19 $(n=35,35 \%)$ was associated with EAT volume (132 \pm 62 vs $\left.104 \pm 40 \mathrm{~cm}^{3}, p=0.02\right)$, age, ferritinemia, and $25 \%$ or more CT lung involvement. ICU admission or death $(n=14,14 \%)$ was associated with EAT volume $\left(153 \pm 67\right.$ vs $\left.108 \pm 45 \mathrm{~cm}^{3}, p=0.015\right)$, hypertension and $25 \%$ or more CT lung involvement. The association between EAT volume and severe COVID-19 remained after adjustment for sex, BMI, ferritinemia and lung involvement, but not after adjustment for age. Instead, the association between EAT volume and ICU admission or death remained after adjustment for all five of these parameters.

Conclusions: Our results suggest that measuring EAT volume on chest CT scans at hospital admission in patients diagnosed with COVID-19 might help to assess the risk of disease aggravation.

Keywords: Epicardial fat volume, Epicardial adipose tissue (EAT), Inflammation, COVID-19

\section{Background}

Early in the current severe acute respiratory syndrome coronavirus 2 (SARS-CoV-2) pandemic, obesity was presumed to be one of the main risk factors for severe forms of Coronavirus Disease 19 (COVID-19) and more recent observational studies showed that between 28.6

\footnotetext{
*Correspondence: helene.bihan@aphp.fr

${ }^{1}$ Department of Endocrinology-Diabetology-Nutrition, CRNH-IdF, CINFO, AP-HP, Avicenne Hospital, Paris 13 University, Sorbonne Paris Cité, Hôpital Avicenne, 125 route de Stalingrad, 93009 Bobigny, France

Full list of author information is available at the end of the article
}

and $47.6 \%$ of COVID-19 patients hospitalized in intensive care units (ICU) were obese [1-3]. The hypothesis for this association is that obesity, and especially visceral obesity, exacerbates COVID-19-related inflammation in patients who already have high levels of inflammation [4].

Besides obesity, impaired metabolic health (hypertension, dyslipidemia, prediabetes and insulin resistance) seems to be one of the main drivers of severe forms of COVID-19 [5]. Outside COVID-19 disease episodes, visceral obesity (defined as an excessive amount of visceral adipose tissue (VAT)) is a better marker of cardiovascular mortality and obesity-related complications than original author(s) and the source, provide a link to the Creative Commons licence, and indicate if changes were made. The images or other third party material in this article are included in the article's Creative Commons licence, unless indicated otherwise in a credit line to the material. If material is not included in the article's Creative Commons licence and your intended use is not permitted by statutory regulation or exceeds the permitted use, you will need to obtain permission directly from the copyright holder. To view a copy of this licence, visit http://creativecommons.org/licenses/by/4.0/. The Creative Commons Public Domain Dedication waiver (http://creativeco mmons.org/publicdomain/zero/1.0/) applies to the data made available in this article, unless otherwise stated in a credit line to the data. 
obesity measured using the body mass index (BMI) [6, 7]. In a cohort of 150 patients, Watanabe et al. reported a strong association between VAT area and the severity of COVID-19 [8]. However, the measurement of VAT volume requires a thoracoabdominal computed tomography $(\mathrm{CT})$ scan which is usually not performed during the management of COVID-19.

Epicardial adipose tissue (EAT) volume can be measured from thoracic CT scans. EAT is located between the myocardium and the visceral pericardium and is considered the heart's VAT [9-11]. It is a highly enriched inflammatory depot with dense macrophage, T-lymphocyte, and mass cell infiltration [12-14]. The main cytokines expressed by EAT are Tumor Necrosis Factor-alpha (TNF-alpha), interleukins 1 and 6 (IL-1, IL-6), leptin, monocyte chemoatractant protein-1 [14]. There is a correlation between EAT volume and upregulation of inflammatory markers, well demonstrated in patients with coronary artery disease $[13,14]$. Moreover, this tissue expresses components of the renin angiotensin aldosterone system [12]. Just as for VAT, this fat depot have been associated with diabetes and various cardiovascular events in longitudinal studies, suggesting that it could be a link coupling diabetes, obesity and cardiovascular disease [11].

Iacobellis et al. suggested an association between EAT and COVID-19 myocarditis [15]. Furthermore, two studies $[16,17]$ suggested that EAT volume could be associated with severe forms of COVID-19. They included very specific populations: patients with very severe forms [16], and in the second, a cohort of Chinese patients under 40 years of age with a low proportion of obesity [17]. However, no such possible association was suggested in a third related study [30,31]. No data on weight were available in the latter. The techniques used to assess EAT volume differed between all three studies. Given this background context, validating whether an association between EAT and severe forms of COVID-19 exists appeared essential.

Accordingly, we aimed to evaluate whether EAT volume could predict COVID-19 severity and admission to ICU or death in multiethnic patients hospitalized after being diagnosed with COVID-19. We also hypothesized that the higher the EAT volume at hospitalization, the higher the percentage of lung involvement on $\mathrm{CT}$ scans also at hospitalization.

\section{Patients and methods}

\section{Design and data collection}

This was a retrospective study performed in Avicenne University Hospital, which is located near Paris, from 7 April to 20 May 2020. Patients were consecutively enrolled in various medical departments (excluding direct ICU admission) to assess the relationship between malnutrition/metabolic profile and aggravation of COVID-19 [18].

Inclusion criteria were as follows: (i) all adult inpatients testing positive for SARS-Cov- 2 infection using real-time reverse transcriptase-polymerase chain reaction in respiratory fluids, and (ii) a thoracic CT scan performed during their hospital stay. We excluded patients with severe comorbidities to avoid any potential bias due to both a poorer global prognosis, and to the risk of ICU admission following disease aggravation during hospitalization. We also excluded HIV-positive patients, as increased EAT volume has been reported in this population [19].

All patients were informed at hospital admission that their medical records could be used for research, unless they opposed. The study was approved by the medical ethics committee of Avicenne University Hospital (CLEA-2020-125). Data were analyzed anonymously.

\section{Study outcomes}

The principal aim of our study was to evaluate whether EAT volume was associated with more severe forms of COVID-19. The primary outcome was severe COVID-19, defined as the need for high-flow nasal oxygen (at least six liters per minute) requiring a face mask [18]. The secondary outcomes were: (a) a composite outcome of transfer to an ICU from a department, and (b) $25 \%$ or more CT lung involvement. Outcomes were considered during the global hospital stay (up to 28 days after admission).

\section{Data collection}

Data were extracted from electronic medical records and included anthropometric characteristics (age, sex, ethnicity, waist circumference, BMI) and comorbidities.

Ethnicity was reported as Caucasian, Arabic (Middle East, Maghreb), Afro-Caribbean (African, African American, Caribbean), Asian (Asian continent). Weight status was defined as: underweight (less than $18.5 \mathrm{~kg} / \mathrm{m}^{2}$ ), normal weight (18.5-24.9), overweight $(\geq 25)$, obese ( $\geq 30)$, with a specific obesity threshold for Asian individuals $\left(<18.5 ; 18.5-23, \geq 23\right.$ and $\geq 27.5 \mathrm{~kg} / \mathrm{m}^{2}$, respectively) [20]. Apart from obesity, four other comorbidities, specifically hypertension, diabetes, cardiovascular disease (i.e., myocardial infarction, stroke), and chronic lung disease, were self-reported or inferred from the use of, respectively, blood pressure, blood glucose, lipid lowering agents, and treatment for chronic lung disease. Data were routinely collected for the following biomarkers on plasma from fasting individuals: white cells $\left({ }^{*} 10^{3} / \mu \mathrm{l}\right), \mathrm{C}$-reactive protein $(\mathrm{CRP})(\mathrm{mg} / \mathrm{dl})$ using immunoturbidimetry with anti-CRP monoclonal antibodies on latex particles, procalcitonin $(\mathrm{PCT})(\mu \mathrm{g} / \mathrm{l})$ using fluorometric sandwich 
immunoassay, ferritinemia ( $\mathrm{ng} / \mathrm{ml})$ using immunoturbidimetry on latex particles, D-Dimers $(\mathrm{ng} / \mathrm{ml})$ using a sandwich immunoassay, fibrinogen (chronometryThrombin Dade) and finally, albuminemia (g/l). A Cobas 6000 analyzer (Roche diagnostics) was used for all biomarkers except fibrinogen where a Siemens analyzer was used.

Albumin can result from both inflammation and malnutrition and was therefore adjusted for CRP using the following formula: albumin $(\mathrm{g} / \mathrm{l})=$ measured albumin $(\mathrm{g} / \mathrm{l})+(\mathrm{CRP}(\mathrm{mg} / \mathrm{l})-15) / 25$. This formula is based on the fact that when CRP is above $15 \mathrm{mg} / \mathrm{l}$, albumin decreases by $1 \mathrm{~g} / \mathrm{l}$ per $25 \mathrm{mg} / \mathrm{l}$ increase in CRP [21].

\section{Lung involvement and EAT volume measurement}

GE (Healthcare Digital, France) or Siemens (Healthineers, France) scanners were used for all CT scans. The extent of typical COVID-19 lesions on chest CT scans was categorized into five groups: 0: no involvement, 1: minimal involvement (i.e., $<$ n $25 \%$ ), 2: $\geq 25-50 \%$, 3: $51-75 \%, 4:>75 \%$. Total adipose tissue around the heart (i.e., pericardial adipose tissue) comprises EAT and paracardial adipose tissue. They are separated by the pericardium, which is not easy to identify [22]. EAT volume was measured using a semi-automatic segmentation technique with a new software package 'AW VolumeShare 7' which is currently being developed by GE (Healthcare Digital, France). The quantity of EAT depot contained in the epicardium and surrounding the coronary artery trees was assessed examining all the axial slices from the thoracic inlet to the beginning of the abdomen. The software automatically delimited the EAT volume (in $\mathrm{cm}^{3}$ ) by summing appropriate pixels using a CT Hounsfield unit (HU) range of between -150 to $-50 \mathrm{HU}$. The software user could readjust the delimitation manually when necessary. These data were collected by IR (see acknowledgments).

\section{Statistical analysis}

Baseline continuous variables were expressed as mean \pm standard deviation (SD). Normality was assessed using the Skewness-Kurtosis test. Categorical variables were expressed as frequencies (percentages). Continuous variables were compared using the Kruskal-Wallis test and categorical variables with the chi-squared $\left(x^{2}\right)$ or Fisher's exact test (depending on the number of patients within each group). All tests were two-sided and had a p-value significance level of 0.05 . To assess correlations between two quantitative variables, the non-parametric Spearman coefficient was used.

Univariable and multivariable logistic regression models were performed to analyze the relationship between EAT volume (per $10 \mathrm{~cm}^{3}$ ) and the three study outcomes with the following models: model 1: unadjusted; model 2: adjusted for age; model 3: adjusted for sex; model 4: adjusted for BMI; model 5: adjusted for waist circumference; model 6: adjusted for ferritinemia; model 7: adjusted for CT lung involvement $\geq 25 \%$. Models 8 and 9 included age, sex and BMI (forced variables) and covariates that were associated with the primary outcome (i.e., severe COVID-19) in univariate analysis $(\mathrm{p}<0.05)$. For model 8 , these were ferritinemia, and $25 \%$ or more CT lung involvement, while for model 9 , they were hypertension and $25 \%$ or more CT lung involvement. We also tested for interactions between EAT volume and both age and sex, separately. Analyses were conducted using STATA software (version 14.2, Texas, USA).

\section{Results}

\section{Population characteristics}

Of the 109 consecutive inpatients who had a CT scan upon hospitalization, we excluded 7 patients (3 with severe comorbidities, 4 HIV-positive patients). EAT volume was measured in 100 of the remaining 102 patients. Table 1 shows the characteristics of our study population. Mean age was $61.7 \pm 16.2$ years. The percentages of obesity, hypertension, diabetes were higher than $40 \%$.

Severe COVID-19 was diagnosed in 35 patients after a mean time of $7 \pm 4$ days between the first symptoms and hospitalization. Following disease aggravation, 11 patients were transferred from non-ICU departments to the ICU $(11 \%)$ where one subsequently died. Three other patients died in non-ICU departments. The four deceased patients were aged between 83 to 89 years old. A total of 18 patients had $25 \%$ or more CT scan lung involvement upon hospitalization.

\section{Determinants of EAT volume}

EAT volume was higher in men than in women, and in individuals with a history of hypertension than in those with no such history (Table 2). It was positively correlated with age, waist circumference and ferritin level, but negatively correlated with albumin level (Table 2).

\section{Parameters associated with severe COVID-19}

Patients with severe COVID-19 were older, had a higher ferritin level, a higher EAT volume, and more severe lung involvement than those without severe COVID-19 (Table 1).

The association between EAT volume (per $10 \mathrm{~cm}^{3}$ : odds ratio 1.12 (95\% confidence interval $1.03-1.23), \mathrm{p}=0.01$ ) and severe COVID-19 remained significant after separate adjustment for sex, BMI, waist circumference, ferritinemia and CT lung involvement. However, it disappeared after adjustment for age $(\mathrm{p}=0.07)$ separately, and after 
Table 1 Characteristics of the study population according to oxygen flow requirement

\begin{tabular}{|c|c|c|c|c|c|}
\hline & $\begin{array}{l}\text { Available data } \\
\mathrm{n}\end{array}$ & $\begin{array}{l}\text { Total population } \\
100\end{array}$ & $\begin{array}{l}\mathrm{O}_{2}<6 \mathrm{I} / \mathrm{min} \\
65\end{array}$ & $\begin{array}{l}\mathrm{O}_{2} \geq 6 \mathrm{l} / \mathrm{min} \\
35\end{array}$ & $p$ \\
\hline Age (years) & 100 & $61.7 \pm 16.2$ & $58.7 \pm 15.8$ & $67.5 \pm 15.5$ & 0.004 \\
\hline Sex (male) & 100 & $63(63.0)$ & $37(56.9)$ & $26(74.3)$ & 0.09 \\
\hline Ethnicity & 100 & & & & \\
\hline Caucasian & & $32(32)$ & $17(26)$ & $32(32)$ & \\
\hline Arabic & & $14(14)$ & $12(18)$ & $14(6)$ & \\
\hline Afro-Caribbean & & $34(34)$ & $23(35)$ & $11(31)$ & \\
\hline Asian & & $14(14)$ & $11(17)$ & $3(9)$ & \\
\hline Other & & $6(6)$ & $2(3)$ & $4(11)$ & 0.08 \\
\hline Body mass index $\left(\mathrm{kg} / \mathrm{m}^{2}\right)$ & 99 & $28.9 \pm 6.26$ & $29.2 \pm 6.1$ & $28.5 \pm 6.6$ & 0.85 \\
\hline Waist circumference $(\mathrm{cm})$ & 91 & $105.3 \pm 16.2$ & $103.5 \pm 17.7$ & $109.8 \pm 10.9$ & 0.01 \\
\hline \multicolumn{6}{|l|}{ Comorbidities } \\
\hline Obesity & 99 & $47(47)$ & $31(47.7)$ & $16(45.7)$ & 0.39 \\
\hline Hypertension & 100 & $54(54)$ & $31(47.7)$ & $23(65.7)$ & 0.09 \\
\hline Diabetes & 100 & $42(42)$ & $24(36.9)$ & $18(51.4)$ & 0.16 \\
\hline Cardiovascular disease & 99 & $17(17.2)$ & $9(14.1)$ & $8(22.9)$ & 0.28 \\
\hline Lung disease & 96 & $5(5.2)$ & $3(4.7)$ & $2(6.1)$ & 0.79 \\
\hline \multicolumn{6}{|l|}{ Biological parameters } \\
\hline White cells $\left({ }^{*} 10^{3} / \mu \mathrm{l}\right)$ & 100 & $7.1 \pm 2.8$ & $7.0 \pm 2.9$ & $7.2 \pm 2.6$ & 0.55 \\
\hline C-reactive protein (mg/dl) & 100 & $82.3 \pm 85.4$ & $72.8 \pm 83.4$ & $100.0 \pm 87.5$ & 0.06 \\
\hline Procalcitonin $(\mu \mathrm{g} / \mathrm{l})$ & 97 & $0.7 \pm 2.3$ & $0.47 \pm 1.7$ & $0.99 \pm 3.0$ & 0.07 \\
\hline Ferritinemia (ng/ml) & 86 & $1128 \pm 2157$ & $723 \pm 735$ & $1812 \pm 3326$ & 0.003 \\
\hline D-Dimers (ng/ml) & 97 & $1629 \pm 2352$ & $1353 \pm 1366$ & $2119 \pm 3447$ & 0.06 \\
\hline Albuminemia $(\mathrm{g} / \mathrm{l})$ & 89 & $33.4 \pm 5.0$ & $34.2 \pm 4.7$ & $32.0 \pm 5.2$ & 0.06 \\
\hline \multicolumn{6}{|c|}{ Computed tomography parameters } \\
\hline$\geq 25 \%$ lung involvement & 99 & $18(18.2)$ & $7(10.8)$ & $11(32.4)$ & 0.01 \\
\hline$\geq 50 \%$ lung involvement & 99 & $6(6.1)$ & $2(3.1)$ & $4(11.8)$ & 0.03 \\
\hline EAT volume $\left(\mathrm{cm}^{3}\right)$ & 100 & $114 \pm 50$ & $104 \pm 40$ & $132 \pm 62$ & 0.02 \\
\hline
\end{tabular}

Data are $\mathrm{n}(\%)$ or mean \pm standard deviation or $\mathrm{n}(\%)$; $\mathrm{p}$-values $<0.05$ are identified in bold case

EAT epicardial adipose tissue

adjustment for age, sex, BMI, ferritinemia and lung involvement combined ( $\mathrm{p}=0.16)$ (Table 3$)$.

\section{Parameters associated with transfer to ICU and/ or mortality}

The 14 patients who were transferred to ICU and/or who died were more likely to have hypertension, 25\% or more CT lung involvement, and a higher EAT volume $\left(153 \pm 45\right.$ vs $\left.108 \pm 67 \mathrm{~cm}^{3}, \mathrm{p}=0.015\right)$ than the other patients (Table 4). EAT volume was associated with the ICU/mortality composite variable (odds ratio per $10 \mathrm{~cm}^{3}$ 1.18 (1.05-1.32), $\mathrm{p}=0.005)$. Multivariable analyses demonstrated that this association was independent of age, sex, BMI, ferritinemia, CT lung involvement when taken separately, and for age, sex, BMI, hypertension and lung involvement when combined (Table 3).

\section{Parameters associated with lung involvement}

The 18 patients who had $25 \%$ or more CT lung involvement had similar parameter values to patients with less lung involvement, apart from a higher CRP level (Table 5). Interestingly, EAT volume was not associated with $25 \%$ or more CT lung involvement $(115 \pm 48$ vs $\left.116 \pm 60 \mathrm{~cm}^{3}, \mathrm{p}=0.95\right)$.

\section{Discussion}

The association we found between EAT and severe COVID-19 was dependent on age, but not dependent on inflammatory or radiological parameters. Admission to ICU or death was associated with a higher EAT volume, independently of all confounders.

\section{Correlation between EAT volume and risk factors}

In line with previous findings, EAT volume was significantly associated with age [23] and with the presence of 
Table 2 Determinants of epicardial adipose tissue (EAT) volume

\begin{tabular}{|c|c|c|c|c|}
\hline Parameters & Modalities & $n$ & EAT volume & $p^{*}$ \\
\hline \multirow[t]{2}{*}{ Sex } & Male & 63 & $130 \pm 48$ & 0.0001 \\
\hline & Female & 37 & $87 \pm 43$ & \\
\hline \multirow[t]{5}{*}{ Ethnicity } & Caucasian & 32 & $133 \pm 60$ & 0.09 \\
\hline & Arabic & 14 & $104 \pm 39$ & \\
\hline & Afro-Caribbean & 34 & $110 \pm 41$ & \\
\hline & Asian & 14 & $93 \pm 40$ & \\
\hline & Other & 6 & $104 \pm 71$ & \\
\hline \multirow[t]{2}{*}{ Obesity } & No & 52 & $113 \pm 49$ & 0.5 \\
\hline & Yes & 47 & $115 \pm 53$ & \\
\hline \multirow[t]{2}{*}{ Hypertension } & No & 46 & $102 \pm 46$ & 0.007 \\
\hline & Yes & 54 & $124 \pm 52$ & \\
\hline \multirow[t]{2}{*}{ Diabetes } & No & 58 & $109 \pm 51$ & 0.10 \\
\hline & Yes & 42 & $121 \pm 49$ & \\
\hline \multirow[t]{2}{*}{ Cardiovascular disease } & No & 82 & $112 \pm 50$ & 0.23 \\
\hline & Yes & 17 & $124 \pm 52$ & \\
\hline Continuous variables & & & Coefficient & $\mathrm{p}$ \\
\hline Age (years) & & & 0.4 & 0.000 \\
\hline Body mass index $\left(\mathrm{kg} / \mathrm{m}^{2}\right)$ & & & 0.09 & 0.32 \\
\hline Waist circumference $(\mathrm{cm})$ & & & 0.30 & 0.004 \\
\hline White Cells (*103/ul) & & & 0.08 & 0.42 \\
\hline C-reactive protein $(\mathrm{mg} / \mathrm{dl})$ & & & -0.03 & 0.74 \\
\hline Ferritinemia (ng/ml) & & & 0.28 & 0.01 \\
\hline D-Dimers (ng/ml) & & & 0.04 & 0.71 \\
\hline Albuminemia (g/l) & & & -0.25 & 0.02 \\
\hline
\end{tabular}

p-values $<0.05$ are identified in bold case

* Spearman's correlation

EAT epicardial adipose tissue

some cardiovascular risk factors, such as hypertension $[11,22]$. Unlike the literature, it was not higher in people with cardiovascular personal history [11] or obesity [24]. However, it was associated with waist circumference, reflecting findings elsewhere [25]. BMI in our population was higher than in most studies that have evaluated EAT volume $[24,26]$. Park et al. demonstrated that the association between EAT thickness and metabolic syndrome was stronger in Asian patients with a $\mathrm{BMI}<27 \mathrm{~kg} / \mathrm{m}^{2}$ [27]. An autopsy-based study found that the association between EAT volume and waist circumference was much stronger than its association with BMI [23]. Finally, ethnicity influences the association between EAT and BMI [28].

\section{Determinants of severe forms of COVID-19}

As in previous studies, we found that age, inflammatory markers (specifically, ferritinemia and CRP), and lung involvement were associated with severe COVID-19 in our study sample $[2,3]$. However, unlike many other studies, neither male gender nor obesity was associated with severe outcomes [1, 3]. Apart the relatively small size of our cohort, this result might be explained by the fact that we selected inpatients who were not hospitalized directly into the ICU department [29]. Only $6 \%$ of them had CT lung involvement $>50 \%$.

\section{EAT volume and severe forms of COVID-19}

The principal findings of our study are the associations between EAT volume and severe COVID-19, and between EAT volume and transfer from a non-ICU medical department to the ICU or death.

Results from three other recent studies have suggested an association between EAT amount and severe forms of COVID-19 in very different populations (younger, highrisk, and monoethnic) and using different definitions for severe forms of COVID-19 [14-16]. We describe these studies below.

First, Deng et al. showed an association between EAT volume and the need for oxygen in young Chinese

Table 3 Risk of adverse outcomes per $10 \mathrm{~cm}^{3}$ increase of EAT volume

\begin{tabular}{lll}
\hline Models & $\mathbf{O}_{\mathbf{2}} \geq \mathbf{6} \mathbf{I} / \mathbf{m i n}$ & Admission to ICU or death \\
\hline 1. Unadjusted & $1.12(1.03-1.23), p=\mathbf{0 . 0 1}$ & $1.18(1.05-1.32), p=\mathbf{0 . 0 0 5}$ \\
2. Adjusted for age & $1.09(0.99-1.20), p=0.07$ & $1.17(1.03-1.32), p=\mathbf{0 . 0 1 4}$ \\
3. Adjusted for sex & $1.11(1.01-1.22), p=\mathbf{0 . 0 3}$ & $1.15(1.03-1.30), p=\mathbf{0 . 0 1 8}$ \\
4. Adjusted for BMI & $1.13(1.03-1.24), p=\mathbf{0 . 0 1}$ & $1.19(1.06-1.34), p=\mathbf{0 . 0 0 4}$ \\
5. Adjusted for waist circumference & $1.15(1.03-1.28), p=\mathbf{0 . 0 1}$ & $1.12(0.98-1.28), p=0.09$ \\
$\begin{array}{l}\text { 6. Adjusted for ferritinemia } \\
\text { 7. Adjusted for CT lung involvement } \geq 25 \%\end{array}$ & $1.14(1.03-1.26), p=\mathbf{0 . 0 1}$ & $1.19(1.06-1.35), p=\mathbf{0 . 0 0 5}$ \\
$\begin{array}{l}\text { 8. Adjusted for age, sex, BMl, ferritinemia and lung involve- } \\
\text { ment } \geq 25 \%\end{array}$ & $1.15(1.04-1.26), p=\mathbf{0 . 0 0 4}$ & $1.19(1.06-1.34), p=\mathbf{0 . 0 0 4}$ \\
9. Adjusted for age, sex, BMl, hypertension and lung involve- & $1.11(0.96-1.27), p=0.16$ & - \\
$\quad$ ment $\geq 25 \%$ & & $1.20(1.01-1.41), p=\mathbf{0 . 0 3}$
\end{tabular}

p-values $<0.05$ are identified in bold case 
Table 4 Characteristics of the study population according to the composite admission to ICU/mortality outcome

\begin{tabular}{|c|c|c|c|}
\hline & $\begin{array}{l}\text { No admission } \\
\text { to ICU or death } \\
n=86\end{array}$ & $\begin{array}{l}\text { Admission to } \\
\text { ICU or death } \\
n=14\end{array}$ & $p$ \\
\hline Age (years) & $60.9 \pm 16.1$ & $67.2 \pm 16.1$ & 0.23 \\
\hline Sex (male) & $51(59.3)$ & $12(85.7)$ & 0.06 \\
\hline Ethnicity & & & 0.74 \\
\hline Caucasian & $27(31)$ & $5(36)$ & \\
\hline Arabic & $13(15)$ & $1(7)$ & \\
\hline Afro-Caribbean & $28(33)$ & $6(43)$ & \\
\hline Asian & $12(14)$ & $2(14)$ & \\
\hline Other & $6(7)$ & $0(0)$ & \\
\hline Body mass index $\left(\mathrm{kg} / \mathrm{m}^{2}\right)$ & $29.0 \pm 6.4$ & $28.4 \pm 5.4$ & 0.68 \\
\hline Waist circumference $(\mathrm{cm})$ & $105.0 \pm 16.8$ & $107.5 \pm 11.6$ & 0.41 \\
\hline \multicolumn{4}{|l|}{ Comorbidities } \\
\hline Obesity & $43(50)$ & $4(28.6)$ & 0.28 \\
\hline Hypertension & $43(50)$ & $11(78.6)$ & 0.047 \\
\hline Diabetes & $36(41.9)$ & $6(42.9)$ & 0.94 \\
\hline Cardiovascular disease & $15(17.7)$ & $2(14.3)$ & 0.76 \\
\hline Lung disease & $3(3.7)$ & $2(14.3)$ & 0.10 \\
\hline \multicolumn{4}{|l|}{ Biological parameters } \\
\hline White cells $\left({ }^{*} 10^{3} / \mu \mathrm{l}\right)$ & $7.0 \pm 2.8$ & $7.8 \pm 2.7$ & 0.22 \\
\hline$C$ reactive protein $(\mathrm{mg} / \mathrm{dl})$ & $77.5 \pm 82.5$ & $111.7 \pm 100.3$ & 0.24 \\
\hline Procalcitonin $(\mu \mathrm{g} / \mathrm{l})$ & $0.4 \pm 1.5$ & $2.0 \pm 4.6$ & 0.13 \\
\hline Ferritinemia (ng/ml) & $883 \pm 854$ & $2386 \pm 4938$ & 0.06 \\
\hline D-Dimers (ng/ml) & $1541 \pm 2353$ & $2150 \pm 2364$ & 0.13 \\
\hline Albuminemia (g/l) & $33.5 \pm 5.0$ & $32.6 \pm 5.2$ & 0.58 \\
\hline \multicolumn{4}{|l|}{ Radiological parameters } \\
\hline$\geq 25 \%$ lung involvement & $10(11.8)$ & $8(57.1)$ & 0.000 \\
\hline EAT volume $\left(\mathrm{cm}^{3}\right)$ & $108 \pm 47$ & $153 \pm 67$ & 0.015 \\
\hline
\end{tabular}

$\mathrm{p}$-values $<0.05$ are identified in bold case

patients $(18-40$ years; $n=65)$, with low percentages of risk factors and obesity [17]. All patients with an EAT volume lower that $105 \mathrm{~cm}^{3}$ had moderately severe COVID-19. In our study, few patients were younger than 40 years and the relationship between EAT and severe COVID-19 disappeared after adjustment for age.

Second, Grodecki et al. also reported an association between EAT volume and CT lung involvement, admission to ICU, invasive mechanical ventilation, vasopressor therapy, and death, in an international registry [16]. These patients, selected because scans highlighted diffuse lung lesions, had severe comorbidities [chronic lung disease (10-26\%), heart failure (13-39\%), coronary artery disease (23-43\%)]; these patients had high intubation (43\%) and mortality (56\%) rates [16]. The EAT volumes were $132 \mathrm{~cm}^{3}\left(88-158 \mathrm{~cm}^{3}\right)$ in the patient group with the poorest prognosis, and $85 \mathrm{~cm}^{3}\left(58-129 \mathrm{~cm}^{3}\right)$ in the group with the best prognosis [16].
Table 5 Characteristics of the study population according to computed tomography lung involvement

\begin{tabular}{|c|c|c|c|}
\hline & $\begin{array}{l}<25 \% \text { CT lung } \\
\text { involvement } \\
n=81\end{array}$ & $\begin{array}{l}\geq 25 \% \text { CT lung } \\
\text { involvement } \\
n=18\end{array}$ & $\mathrm{p}$ \\
\hline Age (years) & $61.2 \pm 15.4$ & $62.9 \pm 19.2$ & 0.81 \\
\hline Sex (male) & $50(61.7)$ & $13(72.2)$ & 0.40 \\
\hline \multicolumn{4}{|l|}{ Ethnicity } \\
\hline Caucasian & $28(35)$ & $4(22)$ & \\
\hline Arabic & $13(16)$ & $1(6)$ & \\
\hline Afro-Caribbean & $26(32)$ & $8(44)$ & \\
\hline Asian & $9(11)$ & $5(28)$ & \\
\hline Other & $5(6)$ & 0 & 0.17 \\
\hline Body mass index $\left(\mathrm{kg} / \mathrm{m}^{2}\right)$ & $29.2 \pm 6.1$ & $28.7 \pm 6.6$ & 0.75 \\
\hline Waist circumference $(\mathrm{cm})$ & $105.3 \pm 16.6$ & $105.6 \pm 14.4$ & 0.73 \\
\hline \multicolumn{4}{|l|}{ Comorbidities } \\
\hline Obesity & $38(47)$ & $9(50)$ & 0.88 \\
\hline Hypertension & $40(49.4)$ & $13(72.2)$ & 0.08 \\
\hline Diabetes & $36(44.4)$ & $5(27.8)$ & 0.19 \\
\hline Cardiovascular disease & $6(7.4)$ & $1(5.6)$ & 0.78 \\
\hline Lung disease & $4(5.1)$ & $1(5.6)$ & 0.94 \\
\hline \multicolumn{4}{|l|}{ Biological parameters } \\
\hline White cells $\left({ }^{*} 10^{3} / \mu \mathrm{l}\right)$ & $6.9 \pm 2.7$ & $8.1 \pm 3.0$ & 0.06 \\
\hline C-reactive protein (mg/dl) & $72.7 \pm 83.2$ & $125.8 \pm 86.4$ & 0.01 \\
\hline Procalcitonin $(\mu \mathrm{g} / \mathrm{l})$ & $0.4 \pm 1.6$ & $1.6 \pm 4.1$ & 0.10 \\
\hline Ferritinemia (ng/ml) & $1101 \pm 2391$ & $1268 \pm 1004$ & 0.09 \\
\hline D-Dimers (ng/ml) & $1550 \pm 2400$ & $1970 \pm 2233$ & 0.40 \\
\hline Albuminemia (g/l) & $33.5 \pm 5.1$ & $33.1 \pm 5.1$ & 0.95 \\
\hline \multicolumn{4}{|l|}{ Radiological parameters } \\
\hline EAT volume $\left(\mathrm{cm}^{3}\right)$ & $115 \pm 48$ & $116 \pm 60$ & 0.95 \\
\hline
\end{tabular}

Third, Abrishami et al. found discordant results on the influence of EAT on COVID-19 prognosis in Iranian patients [30,31]. EAT volume was only associated with upper-zone lung involvement, but not with death. Lower EAT density was a marker of poor disease prognosis/ death [30]. This association disappeared in their multivariable model. Furthermore, the authors had no data on BMI.

Given the heterogeneity between all the cohorts in the above studies and our own, further research is needed to investigate whether certain specific factors modify the association between EAT and prognosis. From our findings and those of the above-mentioned studies, age, ethnicity, obesity and lung involvement seem to be good candidates for such research. 


\section{Explanatory hypotheses}

How can we explain the association we found between EAT volume and severe forms of COVID-19? COVID19 infection, diabetes, and obesity seem to share some common metabolic and inflammation reaction pathways [27, 29, 32-34]. EAT, which is a white adipose tissue, has the highest rates of lipogenesis and fatty acid metabolism among all visceral fat depots, and displays metabolic, thermogenic, and mechanical properties [11]. In addition to studies on cytokines expression in EAT [13, 14], others studies have shown an association between EAT volume and the plasmatic level of certain cytokines (IL15 , IL-15R $\alpha$ [35] and IL-13 [36]), but no correlation with others [37]. Obese patients display higher circulating level of cytokines [38], as higher expression of cytokines in their EAT [39]. Accordingly, we can hypothesize that in patients already at risk, the higher the production of cytokines by EAT, the more intense the cytokine storm.

Higher EAT volumes have been associated with cardiovascular disease and atherosclerosis in patients with diabetes and chronic kidney disease [11, 40, 41]. In COVID-19 infection, 7 and 35\% of patients with COVID19 suffer from cardiac injury [42]; and some authors have suggested that EAT may be a major contributor to SARS-CoV-2 entering the heart $[15,39,43]$, and could be a good predictor of adverse events in patients with a history of cardiovascular disease.

The association between EAT and ferritinemia which we found has not been previously published. This association begs the question of causality. Could it be the case that the EAT amount influences both immune response and production of ferritin by macrophages, in response to infection?

The inverse relationship between albumin and EAT suggests that nutritional status and EAT may be related. Studies have reported reduced EAT thickness 12 months after bariatric surgery $[44,45]$. Accordingly, we need data on weight evolution during a COVID-19 infection to understand the inverse correlation.

\section{Strengths and limitations}

This study was monocentric, assuring that the treatment received was similar for all COVID-19 patients during the period of time considered. Furthermore, the fact that we measured BMI and waist circumference for all patients and included them in the multivariable analyses enabled us to evaluate the influence of EAT on COVID-19 severity prognosis more clearly. The database we used included multiple inflammatory variables, including albumin adjusted for CRP level in order to take into account malnutrition with a view to ensuring model robustness [18].
Furthermore, the technique used to measure EAT volume was robust; by using several axial slices (in $\mathrm{cm}^{3}$ ), we were able to establish the amount of fat much more precisely. EAT volume is often measured with automatic or semi-automatic software because manual methods require excessively long processing times and readings by a radiologist. CT-quantification is challenging and may have different sensitivity and specificity depending on the software used. In contrast, in our study, the pericardial line (which delimits underneath the epicardial fat) was automatically identified by the software and was manually readjusted if necessary. Only $7 \%$ of $\mathrm{CT}$ scans were readjusted by the reader because of minor inaccuracies.

Our study has limitations. The lack of association between EAT volume and BMI may suggest selection bias in the population hospitalized for COVID-19. It may be that rapid weight loss could modify the relationship between BMI, EAT and disease prognosis. As a standardized method for EAT quantification has not yet been determined, different studies have used different Hounsfield unit thresholds to delimit EAT volume [46]. Accordingly, there are no clear threshold values for the physiological or pathological levels of EAT. Moreover, we did not measure EAT attenuation, something which has been suggested elsewhere as a more precise measure of EAT implication in inflammation [47].

Finally, our cohort was relatively small. Nevertheless, multivariable adjustments were possible.

\section{Conclusion}

In this cohort with a high rate of obese patients, mean EAT volume was associated with severity of COVID19 and with transfer from a non-ICU hospital medical department to ICU or death. However, we found no association with lung involvement. Leaving the question of causality aside, it is possible that inflammatory properties of EAT increase systemic inflammation. Further research needs to investigate whether or not the impact of EAT volume on COVID-19 prognosis is dependent on age, sex, BMI or cardiovascular history. Measuring EAT volume upon hospitalization could be useful to precisely determine the prognosis of COVID-19.

\section{Abbreviations \\ BMI: Body mass index; CLEA: Local Committee of Ethics; CT: Computed tomography; COVID-19: Coronavirus Disease 19; CRP: C-reactive protein; EAT: Epicardial adipose tissue; HIV: Human immunodeficiency virus; HU: Hounsfield unit; ICU: Intensive care unit; SD: Standard deviation; SARS-Cov2: Severe acute respiratory syndrome coronavirus 2; TNF-alpha: Tumor necrosis factor-alpha; VAT: Visceral adipose tissue.}

\section{Acknowledgements}

We are very grateful to Dr. Imen Rezgani and Dr. Rachida Mazouzi for their contribution to the data collection. 


\section{Authors' contributions}

$\mathrm{HB}$ prepared and performed the statistical analysis, and co-wrote the manuscript; $A B, R H$ collected the data and reviewed the manuscript; LA, EO, ST, YT, SG, PYB contributed to discussion, and reviewed and edited the manuscript; EC supervised the study and co-wrote the manuscript. All authors read and approved the final manuscript.

\section{Funding}

The authors received no financial support for this research.

\section{Availability of data and materials}

The datasets used and/or analyzed during the current study are available from the corresponding author on reasonable request.

\section{Declarations}

\section{Consent for publication}

Authors give full consent for publication of the present article.

\section{Competing interests}

The authors declare that they have no competing interests.

\section{Author details}

1Department of Endocrinology-Diabetology-Nutrition, CRNH-IdF, CINFO, AP-HP, Avicenne Hospital, Paris 13 University, Sorbonne Paris Cité, Hôpital Avicenne, 125 route de Stalingrad, 93009 Bobigny, France. ${ }^{2}$ Unit of Radiology, Avicenne Hospital, Bobigny, France. ${ }^{3}$ Unit of Intensive Care Medicine, Avicenne Hospital, Bobigny, France. ${ }^{4}$ Department of Infectious Disease, AP-HP Avicenne Hospital, Bobigny, France. ${ }^{5}$ Equipe de Recherche en Epidémiologie Nutritionnelle (EREN), Université Paris 13, Inserm (U1153), Inra (U1125), Centre d'Epidémiologie et Statistiques Paris Cité, Cnam, COMUE Sorbonne-Paris-Cité, 93017 Bobigny, France.

Received: 8 May 2021 Accepted: 28 June 2021

Published online: 20 July 2021

\section{References}

1. Simonnet A, Chetboun M, Poissy J, Raverdy V, Noulette J, Duhamel A, et al. High prevalence of obesity in severe acute respiratory syndrome coronavirus-2 (SARS-CoV-2) requiring invasive mechanical ventilation. Obes Silver Spring Md. 2020;28(7):1195-9.

2. Petrilli CM, Jones SA, Yang J, Rajagopalan H, O'Donnell L, Chernyak Y, et al. Factors associated with hospital admission and critical illness among 5279 people with coronavirus disease 2019 in New York City: prospective cohort study. BMJ. 2020;22(369):m1966.

3. COVID-ICU Group on behalf of the REVA Network and the COVID-ICU Investigators. Clinical characteristics and day-90 outcomes of 4244 critically ill adults with COVID-19: a prospective cohort study. Intensive Care Med. 2021;47(1):60-73.

4. Caër C, Rouault C, Le Roy T, Poitou C, Aron-Wisnewsky J, Torcivia A, et al. Immune cell-derived cytokines contribute to obesity-related inflammation, fibrogenesis and metabolic deregulation in human adipose tissue. Sci Rep. 2017;7(1):3000.

5. Stefan N, Birkenfeld AL, Schulze MB, Ludwig DS. Obesity and impaired metabolic health in patients with COVID-19. Nat Rev Endocrinol. 2020;16(7):341-2.

6. Sahakyan KR, Somers VK, Rodriguez-Escudero JP, Hodge DO, Carter RE, Sochor O, et al. Normal-weight central obesity: implications for total and cardiovascular mortality. Ann Intern Med. 2015;163(11):827-35.

7. Wang $\mathrm{H}$, Chen YE, Eitzman DT. Imaging body fat: techniques and cardiometabolic implications. Arterioscler Thromb Vasc Biol. 2014:34(10):2217-23.

8. Watanabe M, Caruso D, Tuccinardi D, Risi R, Zerunian M, Polici M, et al. Visceral fat shows the strongest association with the need of intensive care in patients with COVID-19. Metabolism. 2020;111:154319.

9. Villasante Fricke AC, lacobellis G. Epicardial adipose tissue: clinical biomarker of cardio-metabolic risk. Int J Mol Sci. 2019;20(23):5989.
10. lacobellis $\mathrm{G}$, Barbaro $\mathrm{G}$. Epicardial adipose tissue feeding and overfeeding the heart. Nutr Burbank Los Angel Cty Calif. 2019;59:1-6.

11. Christensen $\mathrm{RH}$, von Scholten BJ, Hansen CS, Jensen MT, Vilsbø\|l T, Rossing $\mathrm{P}$, et al. Epicardial adipose tissue predicts incident cardiovascular disease and mortality in patients with type 2 diabetes. Cardiovasc Diabetol. 2019;18(1):114

12. Yamada H, Sata M. Role of pericardial fat: the good, the bad and the ugly. J Cardiol. 2015;65(1):2-4.

13. Hirata Y, Tabata M, Kurobe H, Motoki T, Akaike M, Nishio C, et al. Coronary atherosclerosis is associated with macrophage polarization in epicardial adipose tissue. J Am Coll Cardiol. 2011;58(3):248-55.

14. Shimabukuro M, Hirata Y, Tabata M, Dagvasumberel M, Sato H, Kurobe H, et al. Epicardial adipose tissue volume and adipocytokine imbalance are strongly linked to human coronary atherosclerosis. Arterioscler Thromb Vasc Biol. 2013;33(5):1077-84.

15. Malavazos AE, Goldberger JJ, lacobellis G. Does epicardial fat contribute to COVID-19 myocardial inflammation? Eur Heart J. 2020;41(24):2333.

16. Grodecki K, Lin A, Razipour A, Cadet S, McElhinney PA, Chan C, et al. Epicardial adipose tissue is associated with extent of pneumonia and adverse outcomes in patients with COVID-19. Metabolism. 2020;115:154436.

17. Deng M, Qi Y, Deng L, Wang H, Xu Y, Li Z, et al. Obesity as a potential predictor of disease severity in young COVID-19 patients: a retrospective study. Obes Silver Spring Md. 2020;28(10):1815-25.

18. Allard L, Ouedraogo E, Molleville J, Bihan H, Giroux-Leprieur B, Sutton A, et al. Malnutrition: percentage and association with prognosis in patients hospitalized for Coronavirus disease 2019. Nutrients. 2020;12(12):3679.

19. Guaraldi G, Scaglioni R, Zona S, Orlando G, Carli F, Ligabue G, et al. Epicardial adipose tissue is an independent marker of cardiovascular risk in HIV-infected patients. AIDS Lond Engl. 2011;25(9):1199-205.

20. NICE. BMI: preventing ill health and premature death in black, Asian and other minority ethnic groups. Public health guideline; 2013. www.nice. org.uk/guidance/ph46.

21. Lesourd B, Ziegler F, Aussel C. Nutrition in the elderly: importance and traps of biological investigations. Ann Biol Clin (Paris). 2001;59(4):445-52.

22. Dey D, Nakazato R, Li D, Berman DS. Epicardial and thoracic fat - Noninvasive measurement and clinical implications. Cardiovasc Diagn Ther. 2012:2(2):85-93.

23. Silaghi A, Piercecchi-Marti M-D, Grino M, Leonetti G, Alessi MC, Clement K, et al. Epicardial adipose tissue extent: relationship with age, body fat distribution, and coronaropathy. Obes Silver Spring Md. 2008;16(11):2424-30.

24. Rabkin SW. The relationship between epicardial fat and indices of obesity and the metabolic syndrome: a systematic review and meta-analysis. Metab Syndr Relat Disord. 2014;12(1):31-42.

25. Rosito GA, Massaro JM, Hoffmann U, Ruberg FL, Mahabadi AA, Vasan RS, et al. Pericardial fat, visceral abdominal fat, cardiovascular disease risk factors, and vascular calcification in a community-based sample: the Framingham Heart Study. Circulation. 2008;117(5):605-13.

26. Christensen $\mathrm{RH}$, von Scholten $B J$, Lehrskov LL, Rossing $P$, Jørgensen PG. Epicardial adipose tissue: an emerging biomarker of cardiovascular complications in type 2 diabetes? Ther Adv Endocrinol Metab. 2020:11:204201882092882.

27. Park J-S, Ahn S-G, Hwang J-W, Lim H-S, Choi B-J, Choi S-Y, et al. Impact of body mass index on the relationship of epicardial adipose tissue to metabolic syndrome and coronary artery disease in an Asian population. Cardiovasc Diabetol. 2010:9:29.

28. Moharram MA, Aitken-Buck HM, Reijers R, van Hout I, Williams MJ, Jones PP, et al. Correlation between epicardial adipose tissue and body mass index in New Zealand ethnic populations. N Z Med J. 2020;133(1516):22-32.

29. Kompaniyets L, Goodman AB, Belay B, Freedman DS, Sucosky MS, Lange SJ, et al. Body Mass Index and risk for COVID-19-related hospitalization, intensive care unit admission, invasive mechanical ventilation, and death-United States, March-December 2020. MMWR Morb Mortal Wkly Rep. 2021;70(10):355-61.

30. Abrishami A, Eslami V, Baharvand Z, Khalili N, Saghamanesh S, Zarei E, et al. Epicardial adipose tissue, inflammatory biomarkers and COVID-19: Is there a possible relationship? Int Immunopharmacol. 2020;90:107174. 
31. Eslami V, Abrishami A, Zarei E, Khalili N, Baharvand Z, Sanei-Taheri M. The association of CT-measured cardiac indices with lung involvement and clinical outcome in patients with COVID-19. Acad Radiol. 2021;28(1):8-17.

32. Michalakis K, llias I. SARS-CoV-2 infection and obesity: common inflammatory and metabolic aspects. Diabetes Metab Syndr. 2020;14(4):469-71.

33. Sardu C, Gargiulo G, Esposito G, Paolisso G, Marfella R. Impact of diabetes mellitus on clinical outcomes in patients affected by Covid-19. Cardiovasc Diabetol. 2020;19(1):76.

34. The "Diabetes and Cardiovascular Disease (D\&CVD)" Study Group of the European Association for the Study of Diabetes (EASD), Ceriello A, Standl E, Catrinoiu D, Itzhak B, Lalic NM, et al. Issues for the management of people with diabetes and COVID-19 in ICU. Cardiovasc Diabetol. 2020;19(1):114.

35. Dozio E, Malavazos AE, Vianello E, Briganti S, Dogliotti G, Bandera F, et al. Interleukin-15 and soluble interleukin-15 receptor a in coronary artery disease patients: association with epicardial fat and indices of adipose tissue distribution. PLoS ONE. 2014;9(3):e90960.

36. Parisi V, Cabaro S, D’Esposito V, Petraglia L, Conte M, Campana P, et al. Epicardial adipose tissue and IL-13 response to myocardial injury drives left ventricular remodeling after st elevation myocardial infarction. Front Physiol. 2020;11:575181.

37. Fu C-P, Sheu WH-H, Lee I-T, Tsai I-C, Lee W-J, Liang K-W, et al. Effects of weight loss on epicardial adipose tissue thickness and its relationship between serum soluble CD40 ligand levels in obese men. Clin Chim Acta Int J Clin Chem. 2013;421:98-103.

38. Sekikawa A, Kadowaki T, Curb JD, Evans RW, Maegawa H, Abbott RD, et al. Circulating levels of 8 cytokines and marine $n-3$ fatty acids and indices of obesity in Japanese, white, and Japanese American middle-aged men. J Interferon Cytokine Res. 2010;30(7):541-8.

39. Kim I-C, Han S. Epicardial adipose tissue: fuel for COVID-19-induced cardiac injury? Eur Heart J. 2020;41(24):2334-5

40. Cosson E, Nguyen MT, Rezgani I, Tatulashvili S, Sal M, Berkane N, et al. Epicardial adipose tissue volume and coronary calcification among people living with diabetes: a cross-sectional study. Cardiovasc Diabetol. 2021;20(1):35

41. Cordeiro AC, Amparo FC, Oliveira MAC, Amodeo C, Smanio P, Pinto IMF, et al. Epicardial fat accumulation, cardiometabolic profile and cardiovascular events in patients with stages 3-5 chronic kidney disease. J Intern Med. 2015;278(1):77-87.

42. Guo T, Fan Y, Chen M, Wu X, Zhang L, He T, et al. Cardiovascular implications of fatal outcomes of patients with coronavirus disease 2019 (COVID19). JAMA Cardiol. 2020:5(7):811-8.

43. Kim I-C, Kim JY, Kim HA, Han S. COVID-19-related myocarditis in a 21-yearold female patient. Eur Heart J. 2020;41(19):1859.

44. Vasques ACJ, Pareja JC, Souza JRM, Yamanaka A, de Oliveira da MS, Novaes FS, et al. Epicardial and pericardial fat in type 2 diabetes: favourable effects of biliopancreatic diversion. Obes Surg. 2015;25(3):477-85.

45. Launbo N, Zobel EH, von Scholten BJ, Faerch K, Jørgensen PG, Christensen $\mathrm{RH}$. Targeting epicardial adipose tissue with exercise, diet, bariatric surgery or pharmaceutical interventions: a systematic review and metaanalysis. Obes Rev. 2021;22(1):e13136.

46. Commandeur F, Goeller M, Razipour A, Cadet S, Hell MM, Kwiecinski J, et al. Fully automated CT quantification of epicardial adipose tissue by deep learning: a multicenter study. Radiol Artif Intell. 2019;1(6):e190045.

47. Liu Z, Wang S, Wang Y, Zhou N, Shu J, Stamm C, et al. Association of epicardial adipose tissue attenuation with coronary atherosclerosis in patients with a high risk of coronary artery disease. Atherosclerosis. 2019;284:230-6.

\section{Publisher's Note}

Springer Nature remains neutral with regard to jurisdictional claims in published maps and institutional affiliations.
Ready to submit your research? Choose BMC and benefit from:

- fast, convenient online submission

- thorough peer review by experienced researchers in your field

- rapid publication on acceptance

- support for research data, including large and complex data types

- gold Open Access which fosters wider collaboration and increased citations

- maximum visibility for your research: over $100 \mathrm{M}$ website views per year

At BMC, research is always in progress.

Learn more biomedcentral.com/submissions 